\title{
Scrotal oedema: a misadventure of direct vision internal urethrotomy
}

\author{
Siddharth Pandey, Ajay Aggarwal, Apul Goel, Samarth Agarwal
}

Department of Urology, King George's Medical University, Lucknow, India

Correspondence to Dr Siddharth Pandey, sid1420@gmail.com

Accepted 10 August 2018

\section{DESCRIPTION}

A 30-year-old man presented with voiding lower urinary tract symptoms for 2 years due to bulbar urethral stricture. He had a history of appendectomy two and a half years ago during which he was catheterised. His retrograde urethrogram was suggestive of a short $(<1 \mathrm{~cm})$ bulbar urethral stricture (figure 1). After proper counselling, he was posted for direct vision internal urethrotomy (DVIU) under spinal anaesthesia. Immediately following the procedure, he developed scrotal oedema (figure 2). Perineal compression was given along with scrotal support. The patient was observed for 2 days in the ward; there was no increase in the oedema. He was subsequently discharged with an advice to keep a scrotal support and called on the 10th postoperative day. His oedema had completely resolved and his catheter was removed. He voided with a good flow rate of $27 \mathrm{~mL} / \mathrm{s}$ and had a normal bell-shaped curve on uroflow with no residual urine. He was advised to do intermittent self-dilation two times per week. He is doing well 4 months after the procedure.

Sachse first described DVIU in 1974, and even in modern-day urological practice, it is among the most common procedures performed for bulbar urethral stricture disease. The most common technique followed is that originally described by Sachse, which involves cutting the scar tissue at 12 o'clock. ${ }^{1}$ DVIU has best outcomes for urethral strictures that are $<1 \mathrm{~cm}$ in length with minimal spongiofibrosis. The complication rate of DVIU is around $11 \% .^{2}$ The most common complication reported in literature is perineal haematoma with an incidence in literature reported to be as high as $20 \%$ in some series. Scrotal oedema is reported to have an incidence of $\sim 10 \%{ }^{2}$

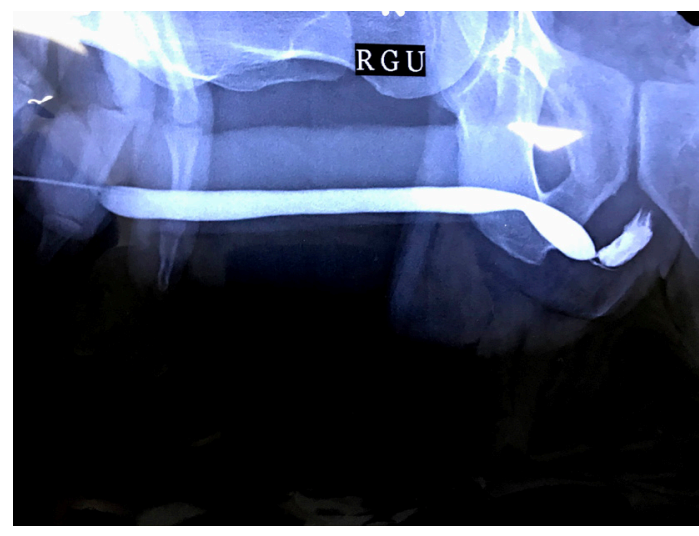

Figure 1 Retrograde urethrogram of the patient showing a short bulbar urethral stricture.RGU, Retrograde Urethrogram

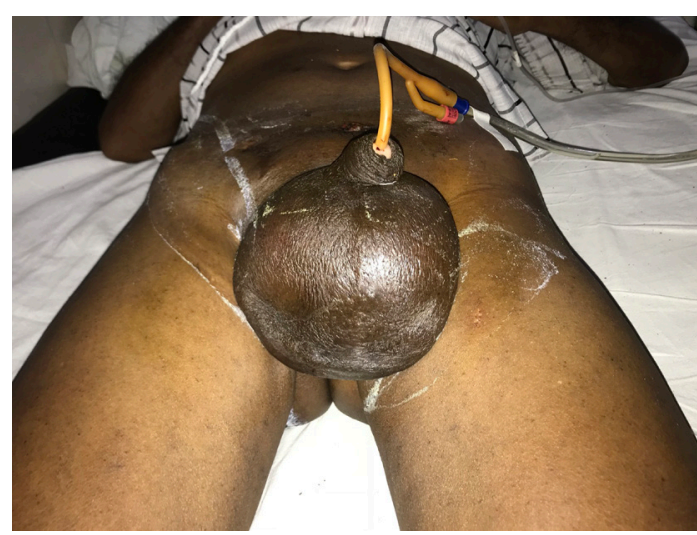

Figure 2 Scrotal oedema that developed immediately after direct vision internal urethrotomy.

The most important thing for a urologist is to know how to prevent these complications. The complications tend to occur when DVIU is 'more than usually traumatic'. Measures that help to prevent complications include the following: (1) placing a guidewire before proceeding with DVIU; (2) cutting at 12 o'clock position to avoid injury to cavernosa; (3) small stepwise cuts by the knife that should be done under vision, avoiding deep cuts; (4) if a single incision is not opening the urethral lumen properly, then multiple radial cuts can be made; (5) the bulb irrigator used during DVIU should be used minimally and with gentle pressure (to avoid extravasation of irrigating fluid). ${ }^{13}$ Scrotal oedema usually occurs because of extravasation of irrigation fluid due to a deep cut, and this was probably the cause in our case. If it at

\section{Learning points}

- Direct vision internal urethrotomy (DVIU) is one of the most common procedures for bulbar urethral strictures and is best suited for strictures $<1 \mathrm{~cm}$ in length with minimal spongiofibrosis.

- Complications usually occur when the procedure is more than usually traumatic, and the best way to prevent them is to place a guidewire and proceed with small stepwise cuts under vision at 12 o'clock with minimal use of the bulb irrigator.

- Scrotal oedema after DVIU is mostly managed conservatively with scrotal support and perineal compression. 
all occurs, then conservative management with scrotal support and perineal compression usually is sufficient.

Contributors SP conceived the case report. SP and AA were major contributors towards writing the manuscript. AA, AG and SP treated the patient and also interpreted the patient data. SP and SA were involved in the review. All authors read and approved the final manuscript.

Funding The authors have not declared a specific grant for this research from any funding agency in the public, commercial or not-for-profit sectors.

Competing interests None declared.
Patient consent Obtained.

Provenance and peer review Not commissioned; externally peer reviewed.

\section{REFERENCES}

1 Kluth LA, Ernst L, Vetterlein MW, et al. Direct vision internal urethrotomy for short anterior urethral strictures and beyond: success rates, predictors of treatment failure, and recurrence management. Urology 2017;106:210-5.

2 Naudé AM, Heyns CF. What is the place of internal urethrotomy in the treatment of urethral stricture disease? Nat Clin Pract Urol 2005:2:538-45.

3 Cotta BH, Buckley JC. Endoscopic treatment of urethral stenosis. Urol Clin North Am 2017:44:19-25.

Copyright 2018 BMJ Publishing Group. All rights reserved. For permission to reuse any of this content visit

http://group.bmj.com/group/rights-licensing/permissions.

BMJ Case Report Fellows may re-use this article for personal use and teaching without any further permission.

Become a Fellow of BMJ Case Reports today and you can:

Submit as many cases as you like

- Enjoy fast sympathetic peer review and rapid publication of accepted articles

Access all the published articles

Re-use any of the published material for personal use and teaching without further permission

For information on Institutional Fellowships contact consortiasales@bmjgroup.com

Visit casereports.bmj.com for more articles like this and to become a Fellow 